Prokkola, E. (2021) Borders and resilience: Asylum seeker reception at the securitized Finnish-Swedish border, 39 (8), 1847-

1864. doi:10.1177\%2F23996544211000062 


\title{
Borders and resilience: Asylum seeker reception at the securitized Finnish-
} Swedish border

\begin{abstract}
Scholars have documented the shift from "open borders" policy and cross-border cooperation towards heightened border securitization and the building of border walls. Since the 2015 migration influx, many countries in the European Union have retained Schengen border controls meant to be temporary. The heightened border securitization has entailed a high level of anxiety among different groups of people and increased societal polarization. This paper moves beyond the politicized threat scenarios and analyzes the resilience processes of the 2015 asylum seeker reception at the securitized EU-internal Finnish-Swedish border and the Finnish border town of Tornio. The asylum reception is studied from the perspective of local authorities and NGO actors who participated in the everyday reception, care and control practices in the stressful border securitization environment of 2015 in Tornio. The examination points out how the success of everyday reception work at the Tornio border crossing ultimately stemmed from the historical openness of the border and on cooperation and trust relations between different actors at various scales. The paper provides a new understanding of the significance of borders and border crossing from the perspective of resilience and highlights the paradox of border securitization. Although border closures are commonly presented as a way to respond to forced migrations, the everyday practices and capacities of the asylum reception at the Finnish-Swedish border were themselves highly dependent on border crossings and cross-border cooperation.
\end{abstract}

Keywords: border, resilience process, securitization, asylum reception, Finnish-Swedish border, polarization 


\section{Introduction}

Borders are sites where the various state and individual interests and strategies of mobility meet, and often collide. During the last decade, the optimistic prospect of a "borderless" world present in the 1990s has vanished and many scholars have documented the shift from an open borders policy and cross-border collaboration towards heightened border securitization and the building of border walls (Brown 2010; Jones 2012; Bromley-Davenport et al. 2018; Paasi et al. 2019). In the European Union, many countries that for decades strived to abolish the barriers that borders create, such as Sweden, Denmark and Germany, have since the 2015 "long summer of migration" reintroduced Schengen border controls which have now become the new normal. Research shows that border closures and border securitization entail a high level of anxiety for migrants, ethnic minorities and cross-border commuters and generally increase societal polarization (Lulle 2019; Van Baar 2017). Yet populists, politicians and security authorities continue to simplistically institute strict border control as the preferred response to perceived domestic security shortcomings and general social malaise.

This paper analyzes resilience processes extant in asylum seeker reception in the context of border securitization at the EU-internal Finnish-Swedish border and the small Finnish border town of Tornio. The southernmost overland Finnish-Swedish border crossing point of Tornio is the busiest land border in Finland; it is travelled across by car annually more than 4 million times (Väylä statistics 2018) and it is common among the local people to walk or bicycle across the border. In 2015, the FinnishSwedish land border crossing point in Tornio formed the key route for more than 32,000 asylum seekers who arrived in Finland. In response, the Finnish state put intensified controls (of foreign nationals) into operation. The tightened border control and especially the participation of military servicemen in the state-led security intervention created an understanding that something very unexceptional and dangerous was taking place in the border area. In this study, the state intervention 
and asylum reception are examined from the perspective of the local actors who participated in asylum reception, care and control practices in the town of Tornio.

Theoretically, the paper aims to develop new knowledge and understanding regarding the role of borders and border crossing in resilience processes. Regardless of the mushrooming interdisciplinary research on resilience, the theoretical and empirical interest towards the role of borders and border crossing in resilience has been modest. In the field of border research and political geography, borders and bordering are seen as a key to understanding the geographies of asylum reception (Mountz and Hiemstra 2014; Pascucci, Kallio and Häkli 2019) and open borders are generally understood to provide economic, social and cultural resources (Sohn 2014). The potential of bridging resilience theories and border studies has only recently sparked interest, however. Wandji (2019) studies the plurality of disruptions created by African postcolonial borders, relating resilience to mundane practices across political borders. XXXX has analyzed the evolution of regional resilience in different geopolitical border areas from the perspective of cross-border mobility. In interdisciplinary migration studies, there is a growing academic and governmental interest towards migrant and refugee resilience. On one hand, the focus is on examining the factors that can explain the adaptation, integration and wellbeing of migrants in a new cultural and institutional environment (e.g. Julca 2011; Scheffran, Marmer and Sow 2012) and on the other hand, migration itself is understood in terms of adaptation (Geddes and Jordan 2012). Moreover, scholars focusing on migration and governance have shown how neoliberal conceptions of resilience, which emphasize self-reliance and selfgovernance, have been mobilized in the domain of humanitarian aid. For example, the UN-led management of refugee camps have implemented community development initiatives, thus presenting the camps as a long-term solution rather than creating political demands for resettlement or return (Ilcan and Rygiel 2015). Bourbeau (2015) argues, however, that although migration scholars have provided a considerable number of studies on migrant and migrant community resilience in 
overcoming various challenges, very little very little theory work has been done in this respect. In security studies, resilience-building is often understood as a move towards de-securitization, yet Bourbeau (2015) argues that the portrayal of migration and refugee movements as a significant disturbance requiring the migrant-receiving countries to adopt resilient strategies has increased the securitization of migration. In politically sensitive contexts the political nature of resilience may be highlighted, which provokes the ethical question of whose entitlement to wellbeing and resilience is made visible and in what ways.

Inspired by the social scientific resilience research and border and migration studies, this study argues that cross-border cooperation, trust relations and unrestricted border crossing are essential for increasing social resilience. The research contributes to the existing debates by offering a study of asylum reception processes in a border region, thus following a relational conception of place and space (Massey 2005) and highlighting the importance of cross-scalar interactions and border crossings for resilience. It is noticed that the multi-scalar nature of resilience and scalar interconnections have been acknowledged already in the original writings on socio-ecological resilience through the notion of panarchy (Walker et al. 2004). By taking cross-border activities and scalar connections as the focus of resilience, this paper takes a critical stance towards the current regime of resilience governance that praises the self-sufficiency of communities and regions as a way to respond to unknown, sudden disruptions (see Joseph 2018). Secondly, by analyzing resilience processes from the viewpoint of political borders and the grassroots activities of asylum reception, the paper responds to the call for increased attention to real life political contestation and normative understanding in resilience (Phelan et al. 2013; Walsh-Dilley and Wolforg 2015).

Before moving on to the Finnish-Swedish border case study, the paper generates a theoretical understanding of the significance of borders and border crossing from the perspective social 
resilience, recognizing the pitfalls and strengths of social scientific resilience research. In governmental documents, and in some interdisciplinary academic resilience debates, forced migration is listed as a change and threat against which societies need to build resilience (e.g. Boin, Comfort and Demchack 2010). Therefore, it is important to highlight that in this study resilience is approached in the wider societal context of border securitization and that the study takes a critical stance towards the governance discourse. From the perspective of the grassroots actors involved in asylum reception in Tornio, the experienced threat did not arise from the interactions between migrants and refugees but from societal conflicts and the mobilization of anti-migration rhetoric/movements. By studying the resilience processes from the grassroots perspective, it is possible to evaluate critically political and populist statements arguing for the limited capacity of the state to receive refugees.

\section{Borders and resilience nexuses}

\section{Resilience in social scientific research}

The concept of resilience is ambiguous and vague and therefore open to continual critical reexamination. The concept has its origins in different disciplines such as mathematics, psychology and ecology (Joseph 2018). In human geographic research, resilience has been copiously examined especially in the context of climate change, regional economic crisis, urban planning and rural and urban communities. The factors commonly understood to explain resilience capacities include diversity: modularity; learning; innovation; collaboration; equality; trust; and sense of community (Wilson 2010; Scherzera, Lujala and Rød 2019; Cutter et al. 2016; Boschma 2015; Lowndes and McCaughie 2013; Smyth and Sweetman 2015). The increasing academic and governmental interest 
towards the concept of resilience can be understood as a response to the experience of "continuous crisis" (Hudson 2010).

In social sciences, the idea of resilience largely developed from social-ecological systems theory in which the interest is on the adaptation, resistance and transformation of complex socio-ecological systems in the context of environmental hazards and disturbances (Walker et al. 2004). Social resilience is often defined, following Neil Adger (2000: 347), as "the ability of groups or communities to cope with external stresses and disturbances as a result of social, political and environmental change". Yet there is no consensus about the exact definition of the term, and different disciplines underline different understandings and epistemic standpoints. Moreover, it has been noted that the application of the notion of resilience, originally stemming from ecological systems theory, in social scientific research is rather problematic from methodological and normative perspectives, and there is much literature discussing how, if at all, social scientific resilience studies are useful and important (Joseph 2018: 13-14; Brown 2013). Joseph (2018) notes that whereas ecological resilience research focuses on environmental shocks, societal resilience research has been extended to include pandemics, economic shocks, terrorism and so on, thus placing resilience first and foremost in cultural, political, and normative contexts (Joseph 2018: 13-14). However, as Brown (2013) notes, "resilience is here to stay" and instead of neglecting the concept, it is more fruitful to work with it from analytical and critical perspectives, and to utilize and explore its analytical potential in different empirical contexts. The epistemic confusion around the concept of resilience is seen to provide not just obstacles but also interesting opportunities for discussing the disciplinary boundaries and normative dimensions of research (Zimmerer 2015).

An overview of the resilience literature points out that in governmental documents and scholarly debates alike, borders are, in a way, implicitly (re-)presented as a key justification and explanation 
for the increasing interest towards the resilience approach. Key international and supra-national organizations have taken global, regional and urban resilience as their objective, arguing that the challenges of the Anthropocene cannot be coped with alone but international cooperation is needed; that is, shared global problems require shared solutions (e.g. UN 2012; Rockefeller Foundation 2019; see also Juncos 2017). A critical question here is how these resilience-building initiatives and expectations are often directed at so-called vulnerable populations and communities (Ilcan and Rygiel 2015; Gressgård 2017). Simultaneously, many western countries have reacted to global crises and vulnerabilities with protectionism and by establishing new border walls.

Also, academic resilience research often tends to naturalize political borders as lines that protect the "inside" from the threats coming from the "outside". The growing interest towards resilience is explained to stem from the fact that the opening of state borders has made places and regions more permeable to the effects of what were previously thought to be external processes (Christopherson et al. 2010: 3). This means that a particular understanding of borders and their functions is reproduced in resilience debates. The imaginary of the risks of a borderless world is employed to make sense of and explain the increasing need for resilience. The well-cited work Designing resilience: Preparing for extreme events provides a fitting example: the authors describe how "societies face an array of potentially devastating threats", then list terrorist attacks, water shortages, infrastructure failures, energy crises, flows of "illegal" immigrants, the effects of climate change, and so on as equivalent examples (Boin, Comfort and Demchack 2010: 2). The concept of resilience is then argued to be a remedy for such unpredictable, urgent threats. This illustrates how the policy documents and many scholarly debates on resilience participate in the production of migration as a question of a securityresilience nexus, proposing tightened border monitoring as a response.

\section{The importance of open borders and border crossing in resilience}


The aim of this paper is to move the discussion on borders, migration and resilience forward by highlighting the importance of open borders and border crossing in resilience and resilience theory. Most researchers agree that resilience necessitates diversity, networks and border crossing; considering this, there has been surprisingly little interest towards theorizing resilience from the perspective of borders or vice versa. In resilience debates, the question of resilience and territorial borders are often connected in rather problematic ways, and there is therefore a need to develop an analytical approach that is more sensitive to borders and their multilayered meanings. Through the concept of resilience, it is likewise possible to pose new questions about borders.

To address the complex question of borders and resilience, the paper revisits the traditional theoretical ideas of resilience in socio-ecological systems that have inspired recent social scientific research and scrutinizes them from the perspective of border studies. It can be argued that that an understanding of borders as determined boundaries of an ecological or territorial "system" actually lies at the core of traditional resilience theories originating from ecology. The idea of the systems change across a number of interconnected spatio-temporal scales is central in the writings of Walker and others (2004) and their attempt to clarify the concept of resilience from the perspective of socio-ecological systems (SES). They approach resilience as the capacity of a system to absorb disturbance and reorganize while undergoing change yet retaining the same function, structure, identity and feedback. However, one of the key questions in current resilience research is whether resilience should be understood as an ability to return to the same condition or whether it is better understood in terms of a successful transformability and renewal (Folke 2006; Boschma 2015).

It is noteworthy that in the highly recognized paper by Walkers et al. (2004), the state is used as an example of "a system", the functioning and resilience of which is dependent on its international 
relations and the relationships between the state and its sub-regions. From the perspective of state borders and territoriality, and social scientific research in general, resilience thinking and the systems theory raise many important questions that need to be scrutinized thoroughly. The history of geopolitics shows that it would even be dangerous to claim that states, regions and communities constitute organic entities. Geographers have critically unpacked how the early geography scholars Rudolf Kjellén's and Friedrich Ratzel's naturalistic and organic conceptions of the state (Lebensraum) and its boundaries (the outer reach of the organic state) were used to justify the violent invasions of the World Wars (Klinke 2018; Holdar 1992). Accordingly, it is important to underline that states, cities, regions and communities are not "organisms", nor do they function according to uniform principles of self-organization (MacKinnon and Derickson, 2012).

Another point that is of interest from the perspective of border research is that the original socioecological theory of resilience includes the notion of crossing scales; the so-called "systems" are not closed entities. In their work, Walker et al. (2004) introduce panarchy as an attribute referring to the relationships between the other resilience attributes (latitude, resistance, precariousness) and how they are influenced by the states and dynamics of the subsystems at scales above and below the scale of interest. Others have further developed the panarchy perspective, illustrating how the resilience of a people, a community or a region depend on their dynamic organization and structuring "within and across scales of space and time" (Allen et al. 2014). Yet, the panarchy element and the connections of the "multi-level world" are often pictured in a rather hierarchical manner (Berkes and Ross 2016). Moreover, Walker and Cooper (2011: 152) argue that the notion of panarchy blurs the limits of the hierarchical adaptive systems that would operate as self-sufficient, territorially bounded entities. Hence it provides a fruitful starting point for pushing the idea of social resilience further in terms of borders and cross-border dynamics. To understand the significance of the dynamics of connections and panarchy in resilience, it is essential to incorporate in the analysis a consideration of the 
boundaries and frictions between the scales and how power has materialized in a historical context (see also Berkes and Ross 2016: 191). The ways of presenting and illustrating social and community resilience as territorially bounded or as relational and open, matter because they foster particular ideas of resilience.

\section{Methods and material for studying the resilience process}

In this study, social resilience processes are approached by scrutinizing the border transitions and consequent practices and capacities of adaptation, resistance and learning in the political and cultural context of the Finnish-Swedish border and the Finnish border town of Tornio. The study focuses on the local actors' perspective, exploring what kind of activities, practices and understandings supported and facilitated the reception of asylum seekers and the work of local actors in the stressful environment of border securitization. Particular focus is on how borders and border crossing are entangled with the social resilience process of the asylum reception in Tornio, which formed the key

route for asylum seekers travelling to Finland and a specific site of state intervention and nationalistic mobilization. While the critical perspectives and governance approach to resilience are important for understanding the recent policy actions and rationales of migration management for instance, such prescriptive methods risk overlooking concrete social actions and experiences (Cote and Nightingale 2012: 478) that are of interest in this research. By following Cote and Nightingale (2012: 480), this study employs a situated approach to resilience, which means that in the analysis of the capacities and adaptation to change, attention is paid to the historical context, cultural values and ethical standpoints of the actors involved in the processes. According to these scholars, to adequately capture the limits of adaptation requires that attention is given to both institutional configurations and the processes and relations that support institutional structures. 
Additionally, particular attention is given to the processes and relations of border crossing and interscalar relations (local, regional, national, cross-border), referred to in terms of panarchy in the resilience literature, in the particular situational, cultural and historical context of the Finnish-Swedish border. By taking the border and border crossing as an analytical lens to resilience processes, it is possible to gain understanding of the significance of societal norms and the reality of political contestation in human societies (Phelan et al. 2013: 202; Walsh-Dilley and Wolford 2015: 175). As border researchers are apt to emphasize, borders are not just markers of state territorial sovereignty, played out in the national and foreign policy discussions of security. Rather, they materialize in contextual and multidimensional ways across various social, economic, political and cultural spheres of life (Paasi et al. 2019; Amilhat Szary and Giraut 2015).

The research material includes policy documents, media reports and nineteen (19) open-ended interviews that were conducted among the municipal authorities and NGO actors who participated in the asylum reception work in Tornio in 2015-2016. Focusing on this particular border location, it was possible to gain an understanding of the situational resilience process by listening to and collecting the stories of different governmental and non-governmental actors regarding the asylum reception work, care and control. While the interview questions mainly focused on the activities and experiences of the participants, the interview stories were embedded more broadly within cultural and ethical considerations of borders, migration and asylum reception. The interview stories through which the actors' practices, experiences and participation in the asylum reception were studied suggest that, at the local level, borders and asylum reception often gain meaning in relation to the personal experiences of people and wider societal discourses. The tape-recorded and transcribed interviews have been stored and encoded according to the guidelines of the Finnish Advisory Board on Research Integrity. In addition, the material includes reports from the Finnish ministries and government and media articles. The state intervention at the Finnish-Swedish border was a temporary 
phenomenon that the local people in the border town needed to cope with but ultimately did not interfere with their mundane activities. The border securitization, however, has had a long-term impact on Finnish society. The border securitization created a highly political and sensitive environment, one in which the local actors' work and social relations in Tornio and Finland were (re)constructed in particular ways.

The interview narratives are interpreted against particular institutional and geopolitical contexts that partly determine the conditions of possibility. The possible co-existence of alternative or contradictory interpretations of resilience is recognized (Simon and Randalls 2016); it is understood that different actors, authorities, officials, NGOs and volunteers may produce their own versions of uncertainties and vulnerabilities and, therefore, ways of coping with the change. Furthermore, it is useful to make an analytical distinction between the authoritative discourses of resilience, manifesting in the statements of governmental actors for example, and the discursive narratives through which people are actually coping with, adapting to, transforming and resisting the disruptive changes in their everyday environment. In border areas, different versions of resilience may intertwine in surprising ways, and people may resist governmental interventions in their everyday life-spheres. Local actors' resilience discourses may also be entangled with long-lasting socio-cultural and geopolitical imaginations of national belonging and otherness (cf. Van Houtum 2010). In the following section, the resilience process is discussed in terms of borders, inter-scalar relations, trust relations, learning processes and social polarization.

\title{
Resilience processes of the asylum reception in Tornio
}

\author{
The "hotspot" of the Finnish-Swedish border
}


The EU-internal Finnish-Swedish border has been relatively open since World War II and the border residents often refer to it as the most peaceful border in the world. The Nordic countries Finland, Sweden, Denmark and Norway have had common "external" borders since a 1957 agreement on the removal of visa requirements between the countries (Finlex 1958/10). In addition, Finland and Sweden have been part of Schengen since 2001; that is, the countries have a double agreement affirming free border crossing. Unlike in many other contexts (e.g. Volmer 2019; Paasi 1996), in the Finnish-Swedish border areas, local residents have not associated this particular geopolitical border with deterrence and fear experiences. Historically, the border has represented a safe passage for Finns compared with the eastern Finnish-Russian border which is often discussed from the perspective of threat and danger (Koch and Vainikka 2019).

The town of Tornio is located adjacent to the Swedish border town of Haparanda and the "twin cities" have had established institutional cooperation since the early 1960s. Since 1987, the institutional cooperation has been conducted in the framework of Provincia Bothniensis, the cooperation organization established between Tornio and Haparanda, and the Council of the Tornio Valley, an organization uniting six border municipalities in Finland and four in Sweden. The roots of the organizations lie in domestic collaboration between border municipalities, which was officially started in Finland in 1923 and in the Swedish Tornio Valley a couple of decades later, in 1941 (Jakola 2016). Finland and Sweden became EU member states in 1995 and the predictability of binational relations has enabled the border towns to boost the economic development of the northern border area through well institutionalized cross-border cooperation. Interaction across the border has been supported by the regional language known as Meänkieli, which is spoken or at least understood on both sides alongside the border (Ridanpää 2014). Since EU membership, which opened up the opportunity to apply for EU-co-funding for cross-border initiatives (INTERREG), the towns of Tornio and Haparanda have strived to construct a common border area. The shared place "on the 
border" includes, among others, a market square, and an international bus station was built along the border in 2013. The station is located immediately next to the border on the Haparanda side but serves as a hub for both Finnish and Swedish regional coach transportation.

The 2015 migration influx and securitization changed the geopolitical meaning of the FinnishSwedish border and the image of Tornio in the minds of people many ways. In mid-September, the Finnish state initiated systematic border surveillance at the Tornio border crossing point and relocated hundreds of security authorities (border guards), servicemen and migration officials there. Contrary to many other EU countries, Finland did not reinstitute the Schengen border controls (Schengen Borders Code, article 29), probably because the country's border guarding resources are fixed along the 1,300-kilometer-long Finnish/EU-Russian border. The Finnish-Swedish border stayed relatively open for daily border crossing and commuting regardless of the border checks that targeted crossborder mobilities and especially foreign nationals. The police-led "enhanced immigration monitoring", based on the Aliens Act (HE 169/2014), that was implemented at the border crossing has been criticized in Finland because it is not always based on evidence-based rules but ethnic profiling. The interviews with local actors show that the sudden presence of state and security officials in the Tornio city center changed the border landscape and the daily border-crossing practices. The interviews indicated that the majority of the local residents supported and adapted well to the border checks, which were seen to bring the migrants under the gaze of the state, although they themselves had been stopped at the border, too. However, several informants told that they had been stopped only few times or not at all because the police could recognize them as locals, Finns or Swedes.

The unusual situation at the norther Finnish-Swedish border crossing point was constantly reported on in national broadcasts in terms of a "crisis", something that also influenced the mindscapes of local residents. Anti-immigration rhetoric and racist tropes were circulated in social media, where asylum 
seekers were portrayed as a threat to European values and national culture (xxxx). The mobilization of anti-migration groups can be interpreted against the long history of nationalism in Finland as well as the austerity politics and wider political turbulence that resulted from the 2015 election in which the nationalistic Finns Party was included in a coalition government. Alongside the historical narratives of migration that were put to work in the media and by politicians to justify stances for or against border controls, the threat scenarios were rationalized by referring to the carrying capacity of the Finnish state, as if the state system would somehow collapse due to the newcomers. For instance, Minister of the Interior Petteri Orpo warned that "at some point, the carrying capacity of Finland is met" (Suomen kantokyky tulee jossain vaiheessa vastaan) (Orpo quoted in Pettersson 2015). The governmental statements mobilized a specific understanding of the Finnish state as a precarious system and entity of which the carrying capacity, functioning and identity were under serious threat. The state precariousness narrative provides a fitting example of how the political resilience discourse is constructed; instead of being worried about human resilience and the precarious situation of the migrants, attention was directed to the carrying capacity of the state. Generally speaking, the securitization of borders and migration is characterized by these kinds of statements (Bourbeau 2015). The nationalistically charged atmosphere concerned many Finns and a number of pro-migration groups mobilized to provide support for the asylum seekers and the reception process, some even by offering them private accommodation (Merikoski 2020).

\section{Establishing order/border}

The governance of the asylum reception system in Finland is state-led, yet the implementation takes place in partnership with municipalities and non-governmental organizations (Wahlbeck 2019). The Finnish Red Cross has a significant role as it supports the authorities and establishes reception centres upon the request of the Finnish Immigration Service. The urgent need for reception facilities in 2015 
had a considerable and visible impact on many municipalities and non-governmental organizations in Finland due to the establishment of new asylum reception infrastructures, services and modes of action (The Union of Municipalities 2016). The scale of the asylum seeker reception is illustrated by the numbers: from January 2014 to January 2015 the total number of reception units in the Finnish municipalities increased from 20 to 144 (EMN 2016: 22).

Simultaneously as the national media was overloaded by the threat discourses, in the hotspot of Tornio, authorities, professionals and grassroots actors from different organizations strived to organize their activities and agree on their responsibilities in the asylum reception work. Tornio formed the gateway to Finland and it was considered important that the state "gaze" would reach the asylum seekers immediately and that they would be guided though the system. The binational bus station on the border become the key site of non-governmental reception work, a place where the Finnish and Swedish parishes and volunteers first welcomed and instructed the newcomers. The exact border line marked a legal-authoritative boundary in relation to which the activities and responsibilities of the authorities were organized. While the state and municipality authorities' powers and actions were territorially limited, the borderline did not form a similar obstacle to nongovernmental actors and they were able to provide care in a more flexible manner on both sides of the border. According to the interviews, the only restriction was that the volunteers needed to be careful not to accidentally participate in human smuggling by physically assisting unauthorized border crossing, for example by carrying a refugee child across the border. The interviews and the governmental reports (eg. Jalava et al. 2017) point out how among the governmental and nongovernmental actors and volunteers the ability to cross the administrative and sectoral borders become a highly important asset in the reception work: 
We (the city authorities) were in contact every day, the Finnish police, customs and the border guard and Migri (Finnish Migration Service) and SPR (Finnish Red Cross). We had advance information about the number of newcomers, how many coaches would soon arrive here. And how many people had started their travel from Stockholm by train and by other means, and through this we were able to react and be ready with a few hours' preparations. (Tornio 3; authority, translated by the author)

In September 2015, the Finnish government and the town of Tornio agreed on the establishment of a state registration center in Tornio. The center provided temporary shelter and after the registration, asylum applicants were transferred to reception centres in other parts of the country. Together with the quick decision to open the public service of asylum accommodation to private markets, the establishment of the registration center on the premises of the former upper secondary school in the middle of the Tornio city center (Tornion Lyseo) serves as an example of a novel concrete solution and arrangement in the Finnish context. The new solutions and transformation enabled the authorities, together with the NGOs, to manage and organize the asylum reception process in a short period.

Moreover, a recognizable narrative shift can be read from the interview stories describing the Tornio city landscape and the newcomers. The first weeks were described in terms of chaos and uncertainty. The state intervention and especially the establishment of the state registration center was experienced as a turn towards order and predictability. Before the state intervention, for example, local people were annoyed that the newcomers were eating berries from their private gardens. The center and the new operation model of the reception work proved to be a well-functioning method for carrying out the asylum seeker reception, and according to the interviewed authorities, the new reception model soon decreased the opposition to the arrangement in the Tornio city council, too. Yet, the social media 
debates show that some local people continued to resist the arrangements and insisted that Finland should not grant the migrants asylum (xxxx).

\section{Inter-scalar relations and trust}

Social capital, confidence and functioning institutions are usually considered factors that strengthen resilience (Cutter et al 2016; Scherzera, Lujala and Rød 2019) and their significance emerged in the local actors' interview stories. The stories and descriptions of the reception work emphasized confidence in security authorities (police, in particular) and the functioning of inter-scalar cooperation between the different actors at the separate stages of the asylum seeker reception. Nationally significant was the role of the local authorities, who worked in close collaboration with experts from national organizations. The well-functioning organization and participation created the feeling of safety and control among the volunteers and NGO actors too. The asylum seeker reception as an everyday practice was strongly supported by previous experiences of institutional cooperation and entailed trust:

It created security that we are cooperating with Haparanda (Sweden), we know people there. When something happens, it is possible to contact them immediately and to ask what is happening, and the other way round. There will be someone that I know personally. (Tornio 1; authority)

Many different actors participated in the practices that helped to create the feeling of safety in the asylum reception work. In the securitized environment, most of the practices and activities that helped to produce safety, order and the feeling of trust were connected with very concrete matters, such as the infrastructure, functionality of the built environment and the general fluency of the care and 
reception activities. Both local experts and those who had arrived from the southern parts of the country learned new ways of working and together developed new operational models. In the interviews, the effectiveness and cooperation between authorities was often mentioned as well as the perceived strengths of the national working culture and the common ambition among the people who participated in the reception and maintenance of the asylum seekers. In addition, the importance of trust-building and (personal) relationships emerged in several interview stories. The shared sense of confidence in the reception work appeared especially in the mundane meetings where the local actors experienced that they shared the same type of worldview and ambition to manage the situation with other actors. The feelings of togetherness and common cause came up in the interviews as significant factors supporting their adaptation and wellbeing:

They (Finnish Red Cross) have people whose values are somehow right. When they are taking action ... they act and there are never problems for them. Whatever obstacles there are, they will solve it and they have the proper means to do it. (Tornio 8; NGO)

The actors' stories highlighted the importance of the cultural values and norms of Finnish society like equality and modesty (which, in this case, was expected especially from the newcomers) and that that order and rules were followed in everyday operations and arrangements. The maintenance of order was considered important for the feeling of safety among the local people as well as for protecting the most vulnerable groups of migrants, children, unaccompanied women and sexual minorities. The willingness to participate and the experiences of safety during the work were strengthened when the actors saw that the working methods were in line with their own conceptions of justice and fairness. Moreover, many of the NGO actors had some previous experience working together with the authorities, which further supported their cooperation. The close cooperation between the ministries, municipalities and NGOs has been regarded as one of the most significant factors explaining 
Finland's success in taking care of, accommodating and providing services to ten times the number of asylum seekers compared with previous years (Jalava et al. 2017). In the Tornio border town, crossborder cooperation networks and existing trust relations played an equally important role in the process.

\section{Open border, a regional resilience factor}

Previous studies have shown that successful resilience processes in sudden, stressful situations and events of disruption often necessitate international cooperation (Rhinard and Sundelius 2010). The research in Tornio supports this notion. Although the long-standing regional and local effort to diminish the border barriers initially seemed secondary with regard to the border security intervention, the examination of the actual practices of asylum reception shows that, ultimately, the open border mentality and trust relations between the regional authorities enabled the actors to maintain smooth and well-functioning operations within and across the border. During the asylum reception process, the significance of the open border, as well as the professional and concrete material help and donations from the Swedish side, was noted by the local participants:

We received many big donations from the Swedish side. The clothes, sets of dishes and so on. ... They contacted us directly from the (Asylum) Reception Center when they needed equipment, clothes for the children and other things. (Tornio 13; NGO)

The effective cooperation and information sharing via various professional and personal international networks enabled the actors to plan, seek resources and prepare themselves for the reception of the newcomers. The personal and professional contacts provided trustful information in a politically and 
socially heated situation in which misinformation circulated and heightened the atmosphere of mistrust.

Without personal and professional networks and trust relations across the border, it would have been highly difficult for the governmental and regional actors to manage their activities effectively and peacefully in the securitized settings. The Finnish and Swedish actors' informal trust relations and somewhat shared perspective on the everyday care work turned out to be valuable for both authorities and NGOs:

Some may think it is unbefitting that we (Finnish and Swedish authorities) drink coffee together and chat. But in the end, it is a cool thing that we know each other, know our colleagues, trust each other and know what the others are doing. (Tornio 2; authority)

Interviewer: There you have people from the Swedish and Finnish sides, so did you discuss a lot about how you should work together?

Informant: It was very hectic and as it started very fast, we did not really have time, but we just shared responsibilities and tasks between us. Eventually, we had a common line in our care work. We did not actually have any differences of opinion. (Tornio 9; NGO)

In Tornio and Haparanda, expertise, social relations and networks have long been created and maintained across the open border. Everyday interaction, commuting and institutional cooperation initiatives provided a particular regional strength in the organization of the asylum reception. The inclusion of diverse stakeholders, skills, sources of knowledge and other resources has been central to the resilience approach (Walker and Cooper 2011: 152) and it is necessary for these to be built and performed across different scales and boundaries. The interviews with NGO actors and volunteers 
pointed out that grassroots cooperation and interaction created security in their everyday work. In Haparanda, for example, the activities of the Finnish NGOs were backed up by the Swedish police and, in turn, the Finnish police had the authority to secure their work in Tornio. Moreover, the interviews revealed that the safety element was essential because NGOs, especially women actors, encountered some harassment and bullying in their everyday work, from local anti-migration-minded people.

The study illustrates the importance of the panarchy perspective, that is, for instance, how the question of trust and safety at one scale - for example, individuals' trust - are not separate from the wider scales and the geopolitical trust relations between states (see also Pain et al. 2010). In Tornio, the wider, historically formed institutional and geopolitical trust relations between Finland and Sweden played an important role in the resilience process of the asylum reception. Many interviewees reported how during the first weeks the authorities, media and citizens in Sweden and Finland had rather contradictory opinions about asylum reception responsibilities. Still, several interviewees emphasized a general confidence in the state, and the historically and culturally formed trust towards Swedish society that enables the countries to maintain good relations during stressful situations.

\section{Learning about asylum reception}

Resilience is not only about being persistent or robust to disturbance. It is also about the opportunities that disturbance opens up in terms of recombination of evolved structures and processes, renewal of the system and emergence of new trajectories. (Folke 2006: 259) 
Learning and prevention are understood as an important part of the resilience process. The implementation of preventive measures and plans requires, however, that there be at least some kind of idea regarding the type of stress situation and transition that regions and communities will face. One explanation for the migration crisis narrative of 2015 in Finland could be that the migration influx and its northern route was something that neither authorities nor citizens could have imagined. The situation was considered exceptional also because Sweden is considered a more attractive destination country for migrants. Furthermore, the common Europe-wide operation models and agreements, such as the responsibility of the first receiving country for the asylum seeker's registration and the processing of the applications (defined by the agreement of Dublin: EU 604/2013), were not fully adhered to during the migration. Many of the interviewed actors discussed the reception work from the perspective of learning and future preparation. It was considered important that in case of similar events, there was now contact information, plans and agreements about the division of work across different scales and sectors within the country:

In the case of a state of exception, we will have contact information, we have plans about who does what, and we all know our roles. (Tornio 2; authority)

The creation of new reception procedures and what some of the interviewees called "the Tornio model" can be seen as a learning process that strengthens regional and national resilience with regard to similar stress situations and transitions. The Tornio model provides a template for state-level planning and preparation should the number of asylum seeker applications significantly increase in the future. It remains to be seen, however, whether there will be enough political will to select and highlight the narrative of a successful asylum reception process in similar stress situations in the future, instead of relying on the old story of the state's limited capacity. Yet, although the model of Tornio is regarded as successful in terms of practical organization and management of the high 
numbers of asylum seekers, it offers a solution only for the first stage of the process. Research shows that there are considerable weaknesses in many stages of the asylum process and that social and emotional resistance to non-western migrants is high in Finland (Pellander and Horsti 2018).

\section{Social polarization and vulnerability}

Resilience includes the notion of precariousness, which in the context of state systems becomes a highly complex and politicized question. The 2015 border and migration securitization had a negative impact on Finnish society, and especially on the lives and sense of security among migrants, promigration actors and all people who were committed to asylum reception work through their professional and personal positions. The increasing number of asylum seekers was loudly opposed by anti-immigrant groups, who organized demonstrations against the openness of the FinnishSwedish border, thus mobilizing societal conflicts and polarization (xxxx 2019; Puustinen et al. 2017). From the perspective of social resilience, it is worth recognizing that the anti-migration rhetoric and the dynamics of the asylum seeker reception were, in many ways, gendered and racialized. The majority of the civil society actors were females, while male actors filled the security sector. The gendered division of the actor groups did not arise in the interviewees' stories as a matter that weakened the safety of the work environment. Yet the gendered divisions of work on migration management and asylum reception practices may, at least to some extent, increase general social polarization $(\mathrm{XXXX)}$.

The wider societal polarization will influence the feeling of safety and trust, increasing precariousness in the long-run, and thus may weaken national and local resilience to stressful situations of all kinds. The opposition to and the fear of societal change, however, should not merely be seen as an inability to adapt to change but also as an integral and important part of the resilience process of open 
democratic societies. The space allowed to resistance can be seen to reflect the persistence of the state's democratic identity, yet there should be clear limits as to what can be counted as constructive criticism and resistance, with a specific focus on prohibiting racism and xenophobic actions.

\section{Conclusions}

Borders and border crossing are central to understanding resilience processes both from the theoretical and empirical point of view. Political borders are highly ambiguous from the perspective of resilience, yet border crossing and their regulations are frequently discussed in terms of resilience. Heightened border security efforts are justified by the arguments that border closures are an effective means to protect the carrying capacity of states and societies. In Finland, the securitization of the EUinternal Finnish-Swedish border was mobilized by politicians and populists by launching threat imaginaries of uncontrolled mass migration. The hegemonic political resilience discourse produced a specific understanding of the Finnish state as a precarious entity whose carrying capacity, functioning and identity were seriously threatened by the forced migrants. The argument over the threshold of national carrying capacity might initially look like a rational and neutral one, and arguments of a similar kind are employed in the context of ecological and economic disturbances, for example complex systems theory is argued to be perfectly in accord with the later philosophy of Friedrich Hayek, a well-known Austrian neoliberal (Walker \& Cooper 2011). In the context of global migration and refugees, however, the employment of resilience discourses can be highly problematic (Ilcan and Rygiel 2015; Bourbeau 2015).

The Finnish case shows the need for scrutinizing high-level political resilience discourses vis-à-vis the actual local resilience processes that are connected to different scaler and border crossings. This 
study of local resilience processes at the securitized Finnish-Swedish border demonstrates that as the state's power materializes at border zones, people simultaneously maintain and establish unique ways of coping with borders and bordering. This kind of cultural and embodied knowhow and trust relations across borders form an important resilience asset that is more likely present in open border contexts and, of course, cannot be generalized to all borders. The historical openness of the FinnishSwedish border and the living with two national institutions have provided people with particular capacities, social capital and trust relations that considerably explained and supported the resilience processes of asylum reception in the hybrid security environment. Accordingly, the findings of this study highlight the paradox of border securitization. Control and surveillance of borders is presented by individual EU states as a way of responding to forced migrations, while at the same time everyday practices and institutional capacity of managing, maintaining and taking care of forced migrants at state border crossing points are highly dependent on cross-border cooperation and relations.

The study maintains that the resilience perspective is valuable precisely because it enables us to highlight the strengths and the resiliences of migrant-receiving societies, thus reorienting the conversation about migration and asylum reception. It can offer new versions of social change and possibilities arising from the grassroots level, something that the critical research on border and migration securitization often leaves aside. The versatile concept of resilience enables us to return to fundamental questions about borders and their societal and normative meaning in the lives of people and societies. The debates about open/closed borders, however, need to be critically interpreted through asking what border crossings and relations are proposed to increase resilience, among whom and where. Open border policy should not be simply presented as a solution to complex global challenges. Not all border crossings in all places increase general societal and ecological resilience, but it matters how and why borders are crossed. It is argued that the neoliberal open borders policy has greatly benefited the global elite. Simultaneously the number of people who are facing expulsion 
from their professional livelihoods and the ecosystems that sustain life is increasing (Sassen 2018), thus forcing people to migrate. Neither the heightened border monitoring nor the fostering of the adaptation processes of migrant communities and refugees offer a sustainable solution. Instead, the resilience capacity of the migrant destination countries and areas as well as the importance of crossborder connections in the asylum reception processes need to be better recognized in political decision making.

\section{References}

Adger, N (2000) Social and ecological resilience: are they related? Progress in Human Geography 24 (3): 347-364.

Allen, C, Angeler, D,. Ahjond, S, Garmestani, L, Gunderson, L, Holling C. S (2014) Panarchy: Theory and Application. Ecosystems 17 (4): 578-589.

Amilhat Szary, A, Giraut, F (2015) Borderities and the politics of contemporary mobile borders. New York: Palgrave Macmillan.

Van Baar, H (2017) Evictability and the Biopolitical Bordering of Europe. Antipode 49 (1): 212-230.

Berkes, H, Ross, B (2016) Panarchy and community resilience: Sustainability science and policy implications. Environmental Science \& Policy 61: 185-193.

Boin, A, Comfort, L, Demchak, C (2010) The rise of resilience. In Comfort, L, Boin, A, Demchak, C (eds) Designing Resilience: Preparing for Extreme Events. University of Pittsburg Press, pp. $1-12$.

Boschma, R (2015) Evolutionary Economic Geography: Towards an Evolutionary Perspective on Regional Resilience. Regional Studies 49 (5): 733-751.

Bourbeau, P (2015) Migration, Resilience and Security. Journal of Ethnic and Migration Studies 41 (12): 1958-1977. 
Bromley-Davenport, H, Mac Leavy, J, Manley, D (2018) Brexit in Sunderland: The production of difference and division in the UK referendum on European Union membership. Environment and Planning C: Politics and Space. doi.org/10.1177/0263774X18804225

Brown, K (2013) Global environmental change I: A social turn for resilience? Progress in Human Geography 38(1): 107-117.

Brown, W (2010) Walled states, waning sovereignty. Cambridge: MIT Press.

Christopherson, S. Michie, J, Tyler, P (2010) Regional resilience: theoretical and empirical perspectives. Cambridge Journal of Regions, Economy and Society 3(1): 3-10.

Cote, M, Nightingale, A (2012) Resilience thinking meets social theory: Situating social change in socio-ecological systems (SES) research. Progress in Human Geography 36 (4): 475-489.

Cutter, S, Ash, K, Emrich, C (2016) Urban-rural differences in disaster resilience. Annals of the American Association of Geographers 106 (6): 1236-1252.

EMN (2016). European Migration Network. Key figures on immigration 2015. Published by European Migration Network \& Finnish Immigration Service, Finland. Accessed October 25, 2017 http://www.emn.fi/files/1361/EMN_maahanmuuton_tunnusl_2015_EN_tumma.pdf

Geddes, A, Jordan, A (2012) Migration as adaptation? Exploring the scope for coordinating environmental and migration policies in the European Union. Environment and Planning $C$ : Government and Policy 30: 1029 - 1044.

Folke, C (2006) Resilience: The emergence of a perspective for social-ecological systems analyses. Global Environmental Change 16: 253-267.

Holdar, S (1992) The ideal state and the power of geography the life-work of Rudolf Kjellén. Political Geography 11 (3): 307-323.

Hudson, R (2010) Resilient regions in an uncertain world? Cambridge Journal of Regions, Economy and Society 3(1): 11-25. 
Ilcan, S, Rygiel, K (2015) "Resiliency Humanitarianism": Responsibilizing Refugees through Humanitarian Emergency Governance in the Camp. International Political Sociology 9 (4): $333-351$.

Jalava, J, Raisio, H, Norri-Sederholm, T, Lahtinen, H, Puustinen, A (2017) Kolmas sektori viranomaisten turvallisuustoiminnan tukena. Valtioneuvoston selvitys- ja tutkimustoiminnan julkaisusarja 75/2017. [Finnish Government's Publication Series]

Jakola, F (2016) Borders, planning and policy transfer: historical transformation of development discourses in the Finnish Torne Valley. European Planning Studies 24 (10): 1806-1824.

Jones, R (2012) Border walls: Security and the war on terror in the United States, India, and Israel. London: Zed Books.

Joseph, N (2018) Varieties of Resilience: Studies in governmentality. Cambridge University Press.

Julca, A (2011) Multidimensional Re-creation of Vulnerabilities and Potential for Resilience in International Migration. International Migration 49 (1): e30-e49.

Juncos, A (2017) Resilience as the new EU foreign policy paradigm: a pragmatist turn? European Security 26 (1): 1-18.

Klinke, I (2018) Friedrich Ratzel, Lebensraum and the death motif. Journal of Historical Geography 61: 97-101.

Koch, K, Vainikka, V (2019) The Geopolitical Production of Trust Discourses in Finland: Perspectives from the Finnish-Russian Border. Journal of Borderlands Studies. doi: $10.1080 / 08865655.2019 .1646152$

Lowndes, V, McCaughie, K (2013) Weathering the perfect storm? Austerity and institutional resilience in local government. Public Finance and Public Choice 41 (4): 533-549.

Lulle, A (2019) "Borderless" Europe and Brexit: young European migrant accounts of media uses and moralities. In Paasi, A, Prokkola, E-K, Saarinen, J, Zimmerbauer, K (eds) Borderless Worlds for Whom? Ethics, Moralities and Mobilities. London: Routledge, pp. 65-77 
MacKinnon, D, Derickson, K (2012) From resilience to resourcefulness: A critique of resilience policy and activism. Progress in Human Geography 37 (2): 253-270.

Merikoski, P (2020) 'At least they are welcome in my home!' Contentious hospitality in home accommodation of asylum seekers in Finland. Citizenship Studies. doi.org/10.1080/13621025.2020.1769558

Methmann, C, Oels, A (2015) From 'fearing' to 'empowering' climate refugees: Governing climateinduced migration in the name of resilience. Security Dialogue 46 (1): 51-68.

Mountz, A, Hiemstra, N (2014) Chaos and Crisis: Dissecting the Spatiotemporal Logics of Contemporary Migrations and State Practices. Annals of the Association of American Geographers 104 (2): 382-390.

Paasi, A (1996) Territories, boundaries, and consciousness: The changing geographies of the Finnish-Russian boundary. London: Wiley.

Paasi, A, Prokkola, E-K, Saarinen, J, Zimmerbauer, K (2019) (eds) Borderless Worlds for Whom? Ethics, Moralities and Mobilities. London: Routledge.

Pain, R, Panelli, R, Kindonc, S, Littled, J (2010) Moments in everyday/distant geopolitics: Young people's fears and hopes. Geoforum 41 (6): 972-982.

Pascucci, E, Kallio, K. P., Häkli, J (2019) "Delay and neglect": the everyday geopolitics of humanitarian borders. In Paasi, A, Prokkola, E-K, Saarinen, J, Zimmerbauer, K (eds) Borderless Worlds for Whom? Ethics, Moralities and Mobilities. London: Routledge, pp. 93107.

Pellander, S, Horst, K (2018). Visibility in mediated borderscapes: The hunger strike of asylum seekers as an embodiment of border violence. Political Geography 66: 161-170.

Pettersson, M (2015) Nyt ministeri Orpo väläyttääkin rajojen sulkemista - mitä se tarkoittaisi? Helsingin Sanomat 21.9.2015 
Phelan, L, Henderson-Sellers, A, Taplin, R (2013) The Political Economy of Addressing the Climate Crisis in the Earth System: Undermining Perverse Resilience. New Political Economy 18 (2): 198-226.

Puustinen, A, H. Raisio, E, Kokki, Luhta, J (2017) Kansalaismielipide: Turvapaikanhakijat ja turvapaikkapolitiikka. Sisäministeriön julkaisu 9/2017 [Finnish Ministry of Interior Publications 9/2017].

Rhinard, M, Sundelius, B (2010) The limits of self-reliance: International cooperation as a source of resilience. In Comfort, L, Boin, A, Demchak, C (eds) Designing Resilience: Preparing for Extreme Events. University of Pittsburg Press, pp. 196-2019

Ridanpää, J (2014) Politics of literary humour and contested narrative identity (of a region with no identity). Cultural Geographies 21 (4): 711-726.

Rockefeller Foundation (2019) 100 Resilient cities network. Available at >https://www.rockefellerfoundation.org/our-work/initiatives/100-resilient-cities-network/< (Accessed 6.9.2019)

Sassen, S (2014) Expulsions: Brutality and Complexity in the Global Economy. Harvard University Press.

Simon, S, Randalls, S (2016) Geography, ontological politics and the resilient future. Dialogues in Human Geography 6 (1): 3-18.

Scheffran, J, Marmer, E, Sow, P (2012) Migration as a contribution to resilience and innovation in climate adaptation: Social networks and co-development in Northwest Africa. Applied Geography 33: 119-127.

Scherzera, S, Lujala, P, Rød, J (2019) A community resilience index for Norway: An adaptation of the Baseline Resilience Indicators for Communities (BRIC). International Journal of Disaster Risk Reduction 36 https://doi.org/10.1016/j.ijdrr.2019.101107 
Smyth, I, Sweetman, C (2015) Introduction: Gender and Resilience. Gender \& Development 23 (3): 405-414.

Sohn, C (2014) Modelling Cross-Border Integration: The Role of Borders as Resource. Geopolitics 19 (3): $587-608$.

UN (2012) Resilient People, Resilient Planet. United Nations Global Sustainability report. Available at: >https://en.unesco.org/system/files/GSP_Report_web_final.pdf< (Accessed 6.9.2019)

Wahlbeck, Ö (2019) National Report on the Governance of the Asylum Reception System in Finland. In Ceaseval Research on the Common European Asylum System (19). Available online at http://ceaseval.eu/publications/WP3_Finland.pdf. (Accessed 21.8.2021)

Vainikka, V, Vainikka, J (2018) Welcoming the masses, entitling the stranger - commentary to Gill. Fennia 196 (1): 124-130.

Walker, B, Holling, C, Carpenter, S, Kinzig, A (2004) Resilience, adaptability and transformability in social-ecological systems. Ecology and Society 9: 2.

Walker, J, Cooper, M (2011) Genealogies of resilience: From systems ecology to the political economy of crisis adaptation. Security Dialogue 42 (2): 143-160

Walsh-Dilley, M, Wolford, W (2015) (Un)Defining resilience: subjective understandings of 'resilience' from the field. Resilience: International Policies, Practices and Discourse 3: 173182.

Wandji, G (2019) Rethinking the time and space of resilience beyond the West: an example of the post-colonial border. Resilience: International Policies, Practices and Discourses 7 (3): 288303.

Van Houtum, H (2010) Human blacklisting: the global apartheid of the EU's external border regime. Environment and Planning D 28 (6): 957-976.

Wilson, G (2010) Multifunctional 'quality' and rural community resilience. Transactions of the Institute of British Geographers 35 (3): 364-381. 
Vollmer, B (2019) The paradox of border security - an example from the UK. Political Geography 71. DOI.org/10.1016/j.polgeo.2019.01.016

Väylä Statistic (2018) Transport statistic. Available from >https://vayla.fi/web/en< (Accessed 6.9.2019).

Zimmerer, K (2015) Understanding agrobiodiversity and the rise of resilience: analytic category, conceptual boundary object or meta-level transition? Un)Defining resilience: subjective understandings of 'resilience' from the field. Resilience: International Policies, Practices and Discourse 3: 183-198. 